
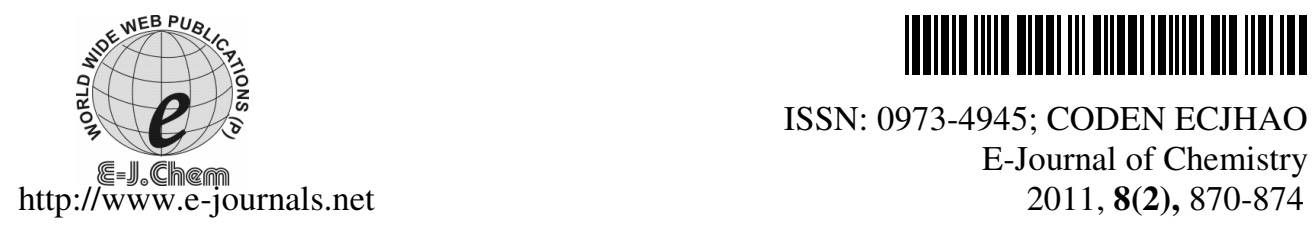

ISSN: 0973-4945; CODEN ECJHAO

E-Journal of Chemistry $2011,8(2), 870-874$

\title{
Seasonal Variation in Groundwater Quality of Yavatmal District, India
}

\author{
P. N. RAJANKAR ${ }^{\S *}$, D. H. TAMBEKAR and S. R. WATE ${ }^{\S}$ \\ ${ }^{\S}$ Environmental Impact \& Risk Assessment Division \\ Neeri, Nagpur-20, India \\ P.G. Department of Microbiology \\ SGB Amravati University, Amravati-02, India \\ prashantrajankar@gmail.com
}

Received 5 August 2010; Revised 20 October 2010; Accepted 20 October 2010

\begin{abstract}
Seventy samples of groundwater were collected from different parts of Yavatmal District, India and analyzed. The results of this analysis were compared with the WHO water quality standards. The groundwater quality in this district showed slightly seasonal variation while the data computed in Water Quality Index (WQI) calculator. The WQI was varied from 73.0 to 80.2 during pre monsoon and 68.7 to 72.4 in post monsoon season, which showed slightly seasonal variation. This may be attributed to surface runoff and percolation process. The results showed that, the water in these areas are bacteriologically not safe and need treatment before it is used for drinking.
\end{abstract}

Keywords: Groundwater, Water quality index, Seasonal variation, Physicochemical parameters, National Sanitation foundation (NSF)

\section{Introduction}

Groundwater is highly valued because of certain properties not possessed by surface water. The groundwater quality is a function of natural processes as well as anthropogenic activities. The safe potable water is enormously essential for living and groundwater is one of the sources for human consumption in both urban as well as rural areas. In India almost 80 percent of the rural population depends on untreated groundwater for potable water supplies ${ }^{1}$. Contamination of drinking water may occur by percolation of toxics through the soil to ground water ${ }^{2}$. Due to continuous population growth demand for fresh water increases rapidly. The growing urbanization and rapid industrialization increase the discharge of polluted water in environment. In rural areas due to lack of awareness and maintenance most of the families carry out the routine activities (cloth washing, utensil washing, bathing, cattle drinking) near to groundwater source, which is one of the reason leading to its contamination. Hence there is need to assess the ground water quality. 


\section{Experimental}

The study area Yavatmal District is located in the eastern region (Vidarbha) of the Maharashtra state of India. The district lies between 19.26' and 20.42' north latitudes and 77.18' and 79.9' east longitudes. The rainfall is not uniform in all parts of the district. The average rainfall of Yavatmal District is $964.7 \mathrm{~mm}$. Most of the total annual rainfall is received during the southwest monsoon season

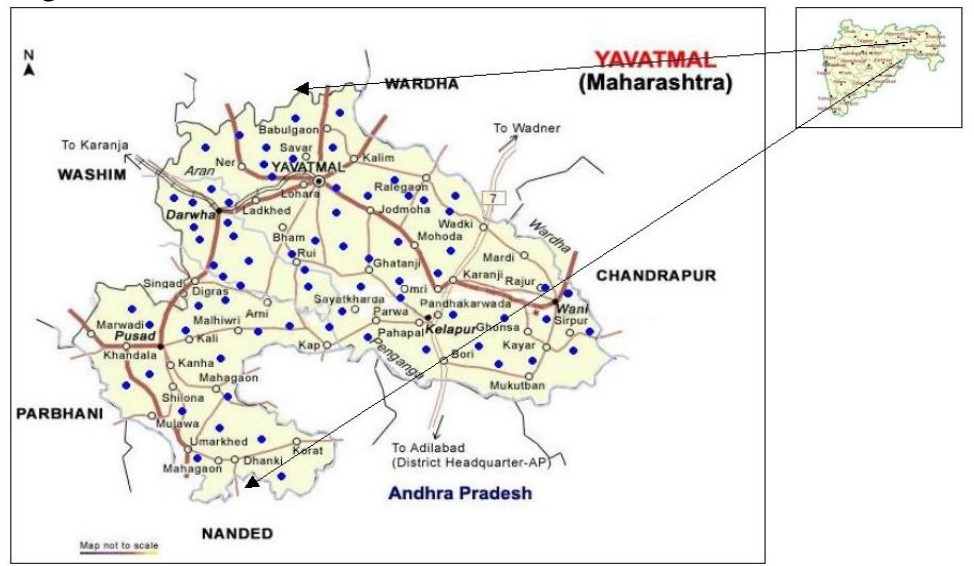

Figure 1. Sampling locations (blue points) in Yavatmal district

\section{Collection of samples}

The sampling locations were in both rural and urban area. Groundwater samples were collected from eleven places of Yavatmal district viz., Arni, Babulgaon, Darwha, Digras, Ghatanji, Kalamb, Maregaon, Pusad, Yavatmal and Zari Jamni, during pre and post monsoon season between 2006 and 2008. Sampling locations are illustrated in Figure 1. Samples were collected in plastic for physicochemical and in sterilized glass bottle for bacteriological quality to avoid unpredictable changes in characteristics. The collected samples were analyzed for important biological and physicochemical parameters such as dissolved oxygen, biochemical oxygen, total coliforms, faecal coliforms, temperature, turbidity, electrical conductivity, total solids, $\mathrm{pH}$, alkalinity, total hardness, calcium hardness, chlorides, sulphate and nitrate.

\section{Biological analysis}

The dissolved oxygen and biochemical oxygen demand was carried out using Winkler's method. In bacteriological examination, total coliforms $\left(28{ }^{\circ} \mathrm{C}\right.$ for $\left.24 \mathrm{~h}\right)$ and faecal coliforms $\left(44.5^{\circ} \mathrm{C}\right.$ for $24 \mathrm{~h}$ ) were determined by Membrane Filtration (MF) technique, and the average values were recorded. The TC was enumerated by M-Endo Agar, (Hi-Media Mumbai) which appeared as metallic sheen colour colonies, and FC was enumerated by M-FC Agar, (Hi-Media Mumbai) which appeared as blue colour colonies.

\section{Physicochemical analysis}

The samples were collected and analyzed as per standard procedure ${ }^{3}$. The temperature of the samples was noted at their sampling point itself. Standard procedure involving spectrophotometry, flame photometry and volumetry were used for the experiment ${ }^{4}$.

\section{Results and Discussion}

The average values of the various biological and physicochemical parameters of the groundwater samples are given in Table 1. 
Table 1. Biological and physicochemical parameters in pre and post monsoon season

\begin{tabular}{|c|c|c|c|c|c|c|c|c|c|c|c|c|c|c|c|c|c|c|c|c|c|c|c|}
\hline \multicolumn{2}{|c|}{ Parameters } & \multirow{2}{*}{ Unit } & \multicolumn{2}{|c|}{ Arni } & \multicolumn{2}{|c|}{ Babulgaon } & \multicolumn{2}{|c|}{ Darwha } & \multicolumn{2}{|c|}{ Digras } & \multicolumn{2}{|c|}{ Ghatanji } & \multicolumn{2}{|c|}{ Kalamb } & \multicolumn{2}{|c|}{ Maregaon } & \multicolumn{2}{|c|}{ Pusad } & \multicolumn{2}{|c|}{ Yavatmal } & \multicolumn{2}{|c|}{ Zari Jamni } & \multirow{2}{*}{ 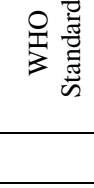 } \\
\hline & & & Pre & Post & Pre & Post & Pre & Post & Pre & Post & Pre & Post & Pre & Post & Pre & Post & Pre & Post & Pre & Post & Pre & Post & \\
\hline \multirow{4}{*}{ 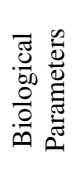 } & DO & \multirow{2}{*}{$\mathrm{mg} / \mathrm{L}$} & 4.2 & 4.7 & 4.3 & 4.4 & 4.1 & 4.2 & 3.4 & 4.0 & 3.6 & 4.2 & 4.2 & 3.9 & 4.4 & 4.1 & 3.7 & 3.9 & 4.1 & 4.5 & 4.2 & 5.0 & 5 \\
\hline & BOD & & 1.7 & 1.9 & 1.8 & 1.8 & 2.0 & 2.0 & 1.7 & 2.0 & 1.6 & 1.7 & 2.0 & 2.0 & 1.8 & 1.9 & 2.1 & 1.6 & 2.0 & 2.0 & 1.7 & 2.1 & 6 \\
\hline & $\mathrm{TC}$ & \multirow{2}{*}{$\begin{array}{c}\text { CFU/ } \\
100 \mathrm{~mL}\end{array}$} & 2.1 & 11.0 & 0.0 & 4.7 & 1.0 & 2.8 & 2.0 & 26.4 & 0.8 & 14.5 & 5.8 & 10.6 & 2.0 & 5.2 & 3.0 & 13.3 & 2.8 & 5.0 & 9.2 & 7.2 & 0 \\
\hline & $\mathrm{FC}$ & & 0.0 & 0.0 & 0.0 & 0.0 & 0.0 & 0.1 & 0.4 & 1.6 & 0.0 & 0.8 & 0.6 & 1.9 & 0.2 & 0.2 & 0.0 & 0.3 & 0.5 & 1.1 & 0.8 & 0.0 & 0 \\
\hline \multirow{11}{*}{ 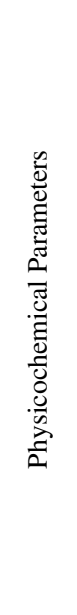 } & Temp. & ${ }^{0} \mathrm{C}$ & 27.6 & 27.1 & 28.5 & 26.8 & 28.4 & 28.2 & 28.3 & 27.9 & 27.4 & 27.0 & 28.6 & 27.4 & 28.5 & 28.5 & 27.7 & 27.3 & 27.7 & 26.7 & 28.5 & 28.1 & 30 \\
\hline & Turb. & NTU & 2.6 & 4.4 & 3.2 & 5.2 & 3.0 & 5.7 & 2.1 & 3.7 & 4.4 & 3.4 & 2.6 & 4.7 & 3.1 & 4.7 & 2.9 & 4.9 & 3.0 & 4.2 & 2.9 & 6.2 & 5 \\
\hline & $\mathrm{EC}$ & $\mu \mathrm{S} / \mathrm{cm}$ & 593.4 & 929.7 & 695.3 & 808.3 & 646.5 & 938.2 & 686.7 & 788.0 & 863.0 & 811.0 & 744.1 & 857.7 & 714.5 & 914.8 & 805.7 & 1120.0 & 626.6 & 1161.5 & 673.5 & 896.0 & 300 \\
\hline & TS & $\mathrm{mg} / \mathrm{L}$ & 264.8 & 457.9 & 270.0 & 422.0 & 280.3 & 420.4 & 315.0 & 402.1 & 422.6 & 526.6 & 311.7 & 436.5 & 331.7 & 427.3 & 392.2 & 510.0 & 285.7 & 454.2 & 273.6 & 441.0 & 500 \\
\hline & $\mathrm{pH}$ & & 8.0 & 8.0 & 8.2 & 8.3 & 7.8 & 7.8 & 7.9 & 8.0 & 7.9 & 8.1 & 8.1 & 8.0 & 7.9 & 7.9 & 7.7 & 8.0 & 7.9 & 8.1 & 7.9 & 8.1 & $7.0-8.5$ \\
\hline & $\begin{array}{l}\text { Total } \\
\text { Alk }\end{array}$ & & 188.6 & 200.5 & 207.2 & 128.6 & 206.0 & 159.8 & 258.3 & 261.0 & 303.0 & 175.3 & 210.7 & 231.0 & 191.3 & 149.1 & 326.7 & 168.8 & 238.0 & 285.1 & 204.5 & 252.8 & 100 \\
\hline & Total H & $\underset{\mathrm{CaCO}_{3}}{\mathrm{As}} \mathrm{mg} / \mathrm{L}$ & 227.0 & 331.3 & 245.3 & 252.0 & 272.5 & 254.2 & 327.9 & 245.1 & 442.0 & 259.3 & 306.5 & 304.4 & 213.2 & 287.5 & 338.0 & 368.0 & 356.0 & 444.9 & 289.3 & 257.5 & 100 \\
\hline & $\mathrm{Ca} \mathrm{H}$ & & 111.0 & 92.1 & 77.0 & 89.3 & 102.4 & 113.2 & 74.9 & 90.6 & 63.5 & 74.3 & 102.8 & 108.2 & 120.2 & 107.8 & 30.0 & 97.3 & 94.0 & 85.3 & 99.2 & 141.8 & 100 \\
\hline & $\mathrm{Cl}^{-}$ & & 75.6 & 61.7 & 77.9 & 109.3 & 86.6 & 83.8 & 79.7 & 95.9 & 111.9 & 164.5 & 51.0 & 102.3 & 33.8 & 81.0 & 143.2 & 88.0 & 96.3 & 87.6 & 34.4 & 106.0 & 200 \\
\hline & $\mathrm{SO}_{4}$ & $\mathrm{mg} / \mathrm{L}$ & 46.8 & 54.9 & 41.1 & 44.9 & 39.2 & 40.7 & 41.9 & 68.4 & 37.6 & 57.8 & 43.6 & 47.0 & 31.1 & 43.1 & 38.2 & 58.7 & 28.1 & 72.6 & 38.9 & 62.5 & 200 \\
\hline & $\mathrm{NO}_{3}$ & & 7.5 & 10.9 & 8.8 & 10.1 & 7.2 & 10.7 & 7.2 & 12.1 & 9.9 & 11.7 & 6.6 & 12.0 & 6.3 & 12.9 & 10.7 & 12.6 & 8.3 & 10.0 & 7.6 & 9.2 & 45 \\
\hline
\end{tabular}

DO-Dissolved Oxygen; BOD-Biochemical Oxygen Demand; TC-Total Coliforms; FC-Faecal Coliforms; Temp-Temperature; Turb-Turbidity; EC-Electrical Conductance; TS-Total Solid; Total Alk-Total Alkalinity ; Total H-Total Hardness; $\mathrm{Ca} \mathrm{H-Calcium} \mathrm{Hardness;} \mathrm{Cl}_{-}$-Chlorides; $\mathrm{SO}_{4}$-Sulphate; $\mathrm{NO}_{3}$-Nitrate ${ }^{0} \mathrm{C}_{-}$ Degree Celsius; NTU-Nephelometric Turbidity Unit; $\mu \mathrm{S} / \mathrm{cm}$-microsiemens per centimeter; mg/l-milligrams per liter; CaCO ${ }_{3}^{-C a l c i u m ~ c a r b o n a t e, ; ~ m g / L-~}$ milligrams per liter; Pre-Pre Monsoon Season; Post-Post Monsoon Season 


\section{Biological parameters}

The dissolved oxygen of all the samples was found in range as compared to the WHO standards. The BOD of the groundwater sample was very low (ranges from 1.6 to $2.1 \mathrm{mg} / \mathrm{L}$ in pre and post monsoon season) which showed that there would not be much organic waste present in the water. The total coliforms were observed in some places in both the season. The faecal coliforms were observed zero in 5 places in pre monsoon season and at 8 places in post monsoon season. This may be attributed to surface runoff and percolation process, thus indicating that the water in these areas are not safe bacteriologically and need treatment before it is used for drinking.

\section{Physicochemical parameters}

All the samples appeared colorless, clear and odorless. The temperature of the sample was lying between 27.4 and $28.6{ }^{\circ} \mathrm{C}$ and 26.7 and $28.5{ }^{\circ} \mathrm{C}$ in pre and post monsoon respectively which was within limit value, the observed turbidity of the groundwater samples in pre and post monsoon season varied from 2.1 to 4.4 NTU and 3.4 to 6.2 NTU respectively, which was within permissible limit except Zari Jamni sample (6.2 NTU) which was slightly higher and that in post monsoon season. The electrical conductance of water samples varied from $593.4 \mu \mathrm{S} / \mathrm{cm}$ to $863.0 \mu \mathrm{S} / \mathrm{cm}$ in pre monsoon season and $788.0 \mu \mathrm{S} / \mathrm{cm}$ to $1161.5 \mu \mathrm{S} / \mathrm{cm}$ in post monsoon season. The observed conductance was very high in both seasons, which may be due to contamination of water sample. Electrical conductivity of water is a direct function of its total dissolved salts ${ }^{5}$. Hence it is an index to represent the total concentration of soluble salts in water ${ }^{6}$. According to WHO standards ${ }^{7}$. the acceptance limit for solids in groundwater is $500 \mathrm{mg} / \mathrm{L}$, which may go up to $1500 \mathrm{mg} / \mathrm{L}$ in case of any alternative sources, but almost all samples in both season were in permissible limit except Ghatnji $(526.6 \mathrm{mg} / \mathrm{L})$ and Pusad $(510 \mathrm{mg} / \mathrm{L})$ water samples which showed slight variation in post monsoon season.

The observed $\mathrm{pH}$ value of all the samples was in the range of 7.7 to 8.2 in pre and 7.8 to 8.3 in post monsoon season, which indicates they were within desirable limit, the mild alkalinity due to bicarbonates. The alkalinity $\left(\right.$ as $\mathrm{CaCO}_{3}$ ) of all the samples was found to be high which may be due to anthropogenic activities. The alkalinity (as $\mathrm{CaCO}_{3}$ ) of the groundwater sample varied from 188.6 to $326.7 \mathrm{mg} / \mathrm{L}$ in pre monsoon season and 128.6 to $285.1 \mathrm{mg} / \mathrm{L}$ in post monsoon season. Total hardness $\left(\mathrm{as}^{\mathrm{CaCO}} \mathrm{C}_{3}\right)$ was high in all samples due to the presence of calcium, magnesium, chloride and sulphate ion, which ranges from 213.2 to $442 \mathrm{mg} / \mathrm{L}$ and 245.1 to $444.9 \mathrm{mg} / \mathrm{L}$ in pre and post monsoon season respectively. The high total would lead to heart disease and kidney stone formation ${ }^{8}$ hence the water available in this area was not suitable for domestic uses. The chloride, sulphate and nitrate in all the samples were within permissible limit in both the season.

\section{Water quality index (WQI)}

The WQI is a reliable means for understanding the overall water quality of the aqua resources. The determination of WQI helps in deciding the suitability of various groundwater sources for designated usage. The use of WQI to determine the water quality of aqua resources is considered as one of the effective tool for comparing water resources ${ }^{9-10}$. In the present study the national sanitation foundation (NSF) WQI calculator was used ${ }^{11}$ and NSF has given the classification of water quality on the basis of WQI rating (Table 2). The WQI values of the samples collected from all the places of Yavatmal district during this study are presented in Table 3. The WQI was varied from 73.0 to 80.2 during pre monsoon and 68.7 to 72.4 in post monsoon season, which showed the seasonal variation in the study area. The groundwater quality was changed from good to medium in some places. 
Table 2. Classification criteria standards based on NSF- WQI

\begin{tabular}{cc}
\hline Water quality index range & Quality of water \\
\hline $90-100$ & Excellent \\
$70-90$ & Good \\
$50-70$ & Medium \\
$25-50$ & Bad \\
$0-25$ & Poor \\
\hline
\end{tabular}

Table 3. Water quality index in Yavatmal district

Parameter $\frac{\text { Arni }}{\text { Pre Post Pre Post Pre Post Pre Post Pre Post }}$ Pre Post Pre Post Pre Post Pre Post WQI $\quad 79.072 .477 .772 .378 .470 .874 .171 .073 .070 .578 .269 .780 .271 .574 .068 .775 .970 .3$

WQI-Water Quality Index; Pre-Pre Monsoon Season; Post-Post Monsoon Season

\section{Conclusion}

The groundwater quality of the study area showed slightly seasonal variation while water quality index values were checked with NSFWQI classification. On some sampling location the quality of water got deteriorated this may due to the anthropogenic activities. Hence there is a need of treatment of groundwater before it is used for consumption.

\section{References}

1. Sudhakar M R and Mamatha P, Curr Sci., 2004, 87(7), 942-947.

2. $\quad$ Sargaonkar A and Deshpande V, Environ Monit Assess., 2003, 89, 43-67.

3. APHA, Standard Methods for the Examination of Water and Wastewater, $20^{\text {th }} \mathrm{Edn}$. American Public Health Association, Washington DC, USA. 1998

4. Nagarajan S, Swaminathan M and Sabarathinam P L, Poll Res., 1993, 12(4), 245.

5. Harilal C C, Hashim A., Arun P. R. and Baji S, J Ecology Environ Conservation, 2004, 10(2), 187-192.

6. Purandara B K, Varadarajan N and Jayashree K, Poll Res., 2003, 22(2), 189.

7. WHO, Guidelines for Drinking Water Quality $2^{\text {nd }}$ Edn., Vol.II. World Health Organization Geneva, 1996

8. $\quad$ Lalitha S and Barani A V, Indian J Environ Protect., 2004, 24(12), 925.

9. Pradhan S K, Patnaik D and Rout S P, Indian J Environ Protect., 2001, 21(4), 355-358

10. Sinha D K and Shrivastava A. K, Indian J Environ Protect., 1994, 14(5), 340-345

11. http://www.water-research.net/watrqualindex/index.htm 


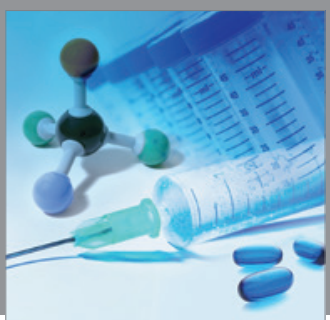

International Journal of

Medicinal Chemistry

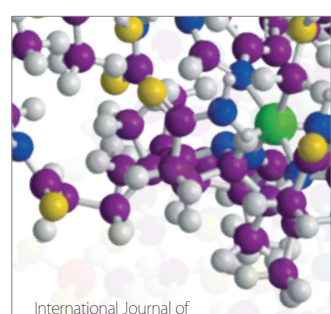

Carbohydrate Chemistry

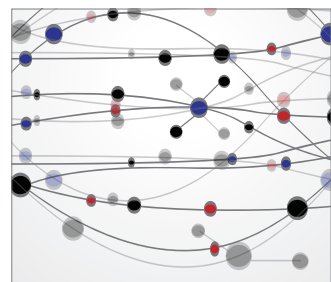

The Scientific World Journal
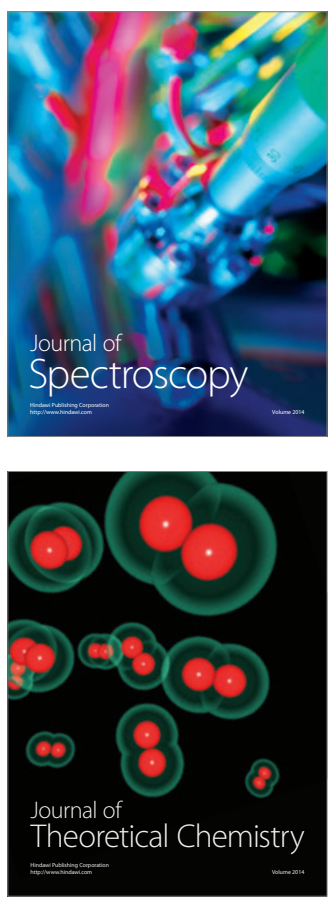
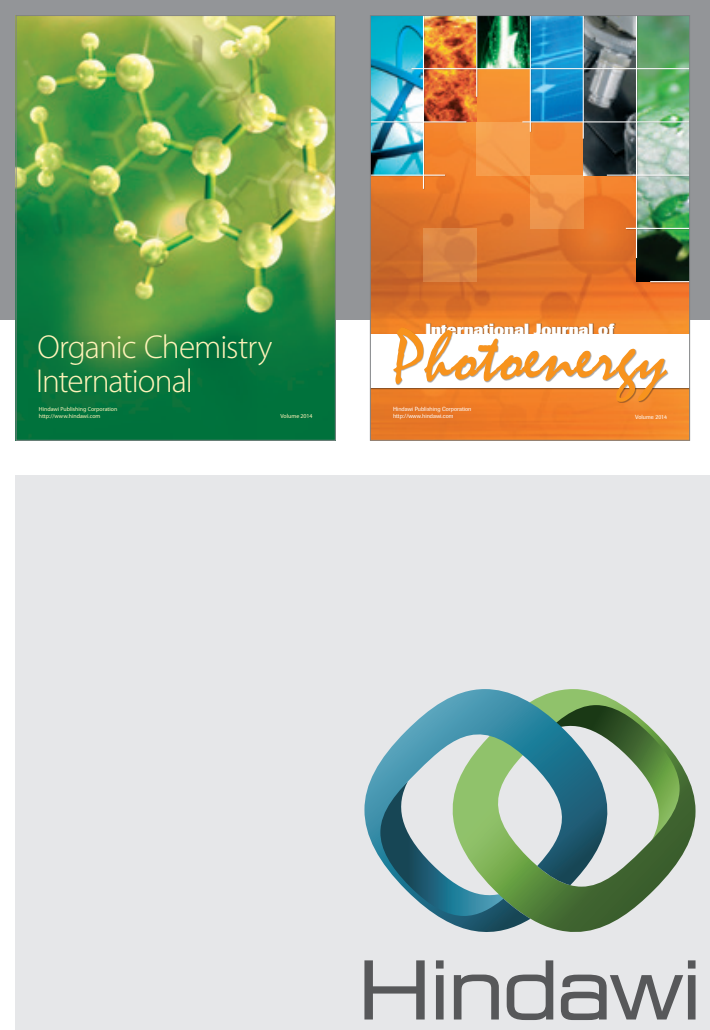

Submit your manuscripts at

http://www.hindawi.com
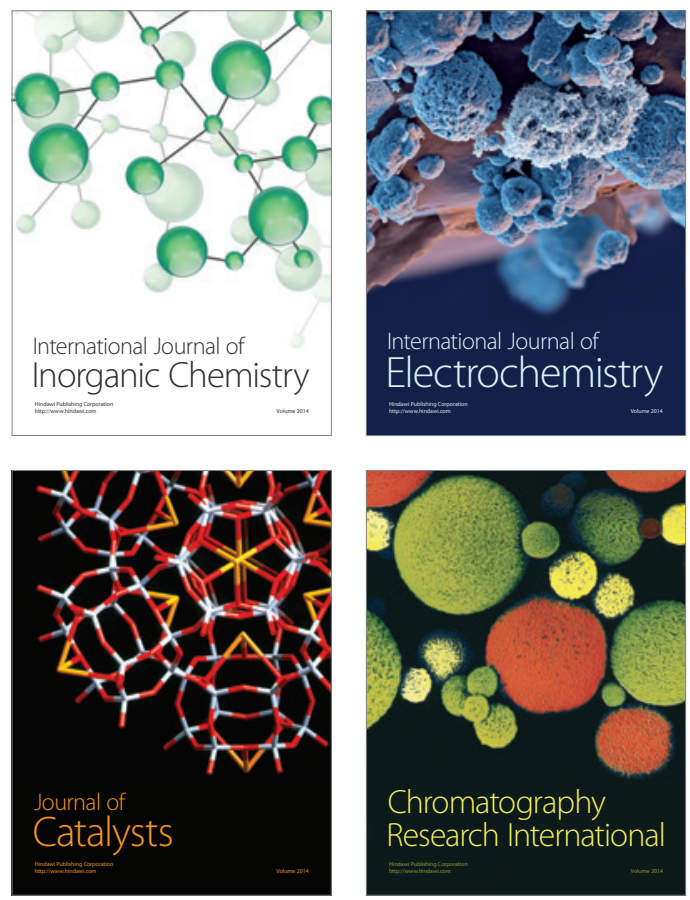
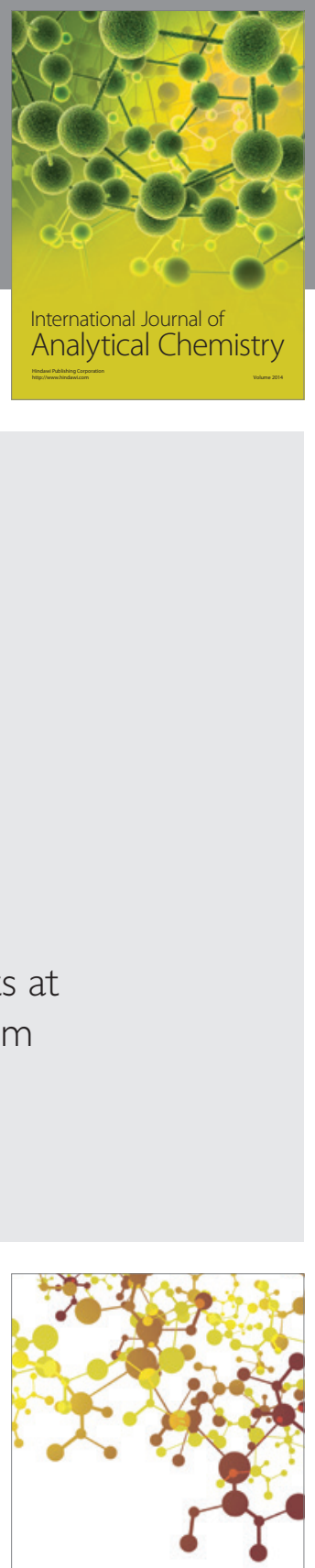

Journal of

Applied Chemistry
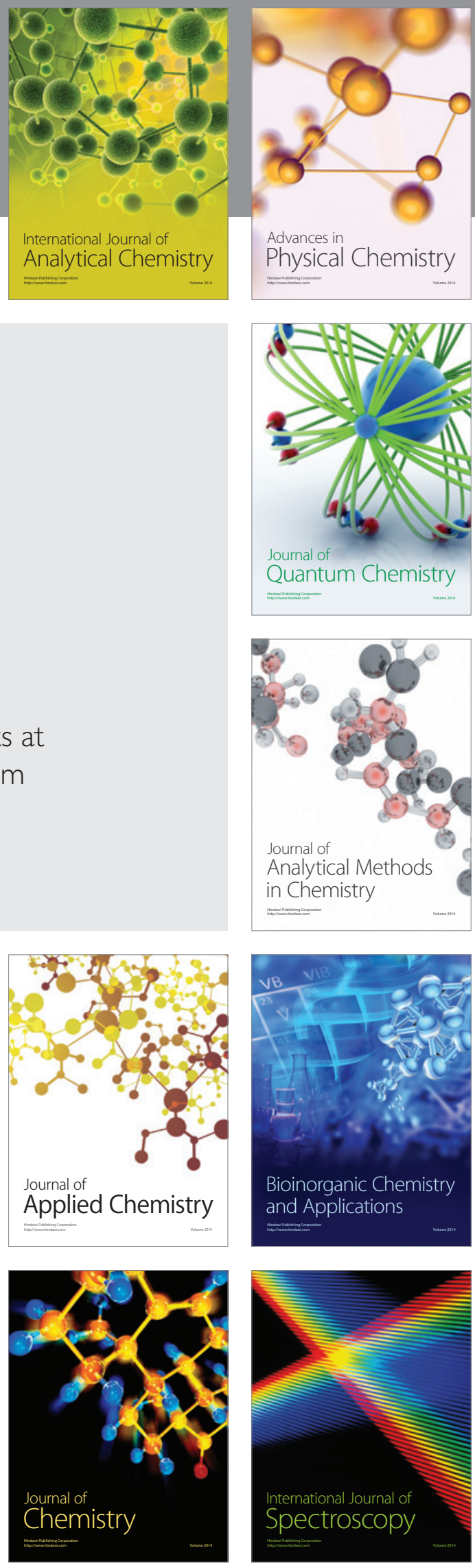